\title{
Experimental and Empirical Time to Corrosion of Reinforced Concrete Structures under Different Curing Conditions
}

\author{
Ahmed A. Abouhussien and Assem A. A. Hassan \\ Department of Civil Engineering, Faculty of Engineering and Applied Science, Memorial University of Newfoundland, \\ St. John's, NL, Canada A1B3X5 \\ Correspondence should be addressed to Assem A. A. Hassan; ahassan@mun.ca
}

Received 2 May 2014; Revised 26 August 2014; Accepted 6 October 2014; Published 16 October 2014

Academic Editor: Hamid Ronagh

Copyright ( 2014 A. A. Abouhussien and A. A. A. Hassan. This is an open access article distributed under the Creative Commons Attribution License, which permits unrestricted use, distribution, and reproduction in any medium, provided the original work is properly cited.

\begin{abstract}
Reinforced concrete structures, especially those in marine environments, are commonly subjected to high concentrations of chlorides, which eventually leads to corrosion of the embedded reinforcing steel. The total time to corrosion of such structures may be divided into three stages: corrosion initiation, cracking, and damage periods. This paper evaluates, both empirically and experimentally, the expected time to corrosion of reinforced concrete structures. The tested reinforced concrete samples were subjected to ten alternative curing techniques, including hot, cold, and normal temperatures, prior to testing. The corrosion initiation, cracking, and damage periods in this investigation were experimentally monitored by an accelerated corrosion test performed on reinforced concrete samples. Alternatively, the corrosion initiation time for counterpart samples was empirically predicted using Fick's second law of diffusion for comparison. The results showed that the corrosion initiation periods obtained experimentally were comparable to those obtained empirically. The corrosion initiation was found to occur at the first jump of the current measurement in the accelerated corrosion test which matched the half-cell potential reading of around $-350 \mathrm{mV}$.
\end{abstract}

\section{Introduction}

Reinforced concrete in severe environments, such as that subjected to high percentages of chlorides, is deteriorating at a quick rate and requires special design consideration to extend its service life. The most critical factor for this deterioration is the corrosion of embedded reinforcing steel [1]. The corrosion requires the chlorides from deicing salts, groundwater, or seawater to penetrate the concrete cover and reach the reinforcing steel. Once the percentage of the chloride around the steel bar exceeds the threshold needed for corrosion initiation, the corrosion starts and is then followed by propagation through steel bars, which eventually leads to a mass loss and destruction of the concrete cover.

Chloride permeability is a significant property of the concrete representing its resistance to chloride ingress. This property directly affects the time for chlorides to reach the reinforcing bars and, consequently, the corrosion initiation time. Most of the models used for corrosion prediction $[2,3]$ account for the resistance of concrete to chlorides. Concrete with low permeability and dense microstructure proved to extend the time needed for corrosion to occur [4]. In fact, the total time to corrosion for reinforced concrete structures can be increased using high performance or less permeable concretes [5, 6]. Hooton et al. [5] tested the effect of six curing regimes on the chloride diffusion coefficients of three different mortar mixtures. They studied the effect of these curing techniques on the time to corrosion for different concrete covers using predictive model. The results from their investigation showed that the mixture composition and curing regimes have a significant effect on the chloride diffusion coefficients and consequently on the predicted times to corrosion [5]. The assessment of chloride permeability of concrete can be performed using one of the following standard tests: rapid chloride penetration test [7] and/or chloride bulk diffusion test [8]. The difference between the two tests in determining the chloride permeability is insignificant [9]. Recently, different models were developed [10] for predicting the time to corrosion of reinforced concrete structures based on the chloride permeability of concrete. Most of these 
models, such as that proposed by Boddy et al. [2], calculate the initiation period as a function of the chloride diffusion through the concrete using a simplified Fickian diffusion approach. The propagation period in these models, however, is not related to the chloride permeability and is usually taken as a constant period starting after the end of the initiation period.

Ehlen et al. [3] also developed another model for predicting the time to corrosion of reinforced concrete structures. Their model was used in developing a commercial software program for predicting the time to corrosion initiation of the structure using some initial inputs parameters. This model is similar to the more complex model proposed by Boddy et al. [2]. The initiation period in this model also relies on the chloride permeability of concrete. However, it accounts for both time and temperature in calculating the coefficient of diffusion of concrete.

On the other hand, El Maaddawy and Soudki [11] developed a mathematical model capable of predicting the time from corrosion initiation to corrosion cracking. Their model uses Faraday's law to relate the steel mass loss to the internal radial pressure as a result of the expansion caused by corrosion products. However, their model did not account for any change of concrete mixture properties (chloride permeability) or curing conditions.

Other researchers have focused on measuring the chloride threshold value and the chloride transport rate based on experimental tests and/or field results. Trejo and Pillai [12] proposed a model for predicting the chloride transport rate in reinforced concrete structures based on the results of an experimental investigation. In their experiment, the diffusion of chlorides towards the steel bars was accelerated by applying a potential gradient across two electrodes. An anode was embedded at the bar surface, while a cathode was placed in a chloride ion solution of $3.5 \%$ concentration. The corrosion initiation was detected by evaluating the polarization resistance of the steel reinforcement by a statistical analysis procedure.

Accelerated corrosion test has been widely used among researchers to induce corrosion of steel embedded in concrete in a relatively short period. This test employs an electrical current along with chloride solution to accelerate the process of corrosion initiation [13]. Although the corrosion initiation times obtained from such accelerated test may be different from the real conditions of structures, it can be used for comparative studies to evaluate the corrosion performance of different concrete mixtures or curing conditions [14]. The accelerated corrosion test has a wide application in studies evaluating the structural performance of corroded reinforcement regarding shear, bond, cover cracking, and flexural strength [15-18]. Moreover, some researchers used the accelerated corrosion test for predicting the time to corrosion based on cumulative damage theory [19].

The current available time to corrosion prediction models are relatively new and need further investigation. In addition, there are limited experimental test methods available in the literature to study the time to corrosion of reinforced concrete. The main purpose of this investigation was to experimentally investigate the time to corrosion of concrete samples to illustrate the different corrosion stages during the entire life of the structure. The investigation includes a comparison between the corrosion initiation times obtained experimentally and those predicted by Fick's second law of diffusion. The effects of concrete cover, concrete quality, and curing condition on the chloride permeability and time to corrosion of the concrete are also studied and discussed in this investigation.

\section{Research Objectives and Significance}

It is not certain whether the current available corrosion prediction models can predict the actual corrosion stage in concrete structures. It is also not certain if the chloride permeability measured experimentally using ASTM C1556 [8] can be used in the prediction models to calculate the actual corrosion stage at any time. The purpose of this paper was to experimentally measure the different times to corrosion (corrosion initiation, cracking, and damage periods) of concrete samples using an accelerated corrosion technique and compare the results to those calculated using Fick's second law of diffusion, which is based on the chloride permeability of concrete. The paper is of special interest to designers concerned with the time to corrosion of reinforced concrete structures, as it demonstrates and discusses the different corrosion stages undergone during the entire service life.

\section{Experimental Program}

A self-consolidating concrete mixture was used in this investigation. The mixture was cured for a total period of 28 days under ten different curing techniques yielding ten different concrete qualities. The experimental program was divided into two parts. In the first part, 50 concrete cylinders were cast. These concrete cylinders were used in testing the compressive strength and the chloride permeability of the concrete. The chloride permeability was examined using the rapid chloride penetration test (RCPT) and chloride bulk diffusion test according to ASTM C1202 [7] and ASTM C1556 [8], respectively. Based on the results obtained from the chloride bulk diffusion test (ASTM C1556), the apparent chloride diffusion coefficient $\left(D_{a}\right)$ and the diffusion decay index $(m)$ at 28 days were calculated for the ten samples representing the ten different curing techniques. The values of $D_{a}$ and $m$ were then exploited for predicting the time to corrosion of each concrete sample by applying Fick's second law of diffusion.

In the second part, an accelerated corrosion test was implemented on 80 concrete prism samples containing one embedded steel bar at the middle of each prism. The prism samples were cast with the same mixture and cured under the same ten different curing techniques in order to measure the corrosion initiation, cracking, and damage periods for all tested samples. The accelerated corrosion test was utilized to compare the predicted results obtained from the first part (Fick's second law of diffusion) with those obtained experimentally. In the accelerated corrosion samples the 
TABLE 1: Mixture proportions.

\begin{tabular}{lcccccc}
\hline Concrete type & Cement $\left(\mathrm{kg} / \mathrm{m}^{3}\right)$ & W/B & $10 \mathrm{~mm}$ stone $\left(\mathrm{kg} / \mathrm{m}^{3}\right)$ & Sand $\left(\mathrm{kg} / \mathrm{m}^{3}\right)$ & Water $\left(\mathrm{kg} / \mathrm{m}^{3}\right)$ & HRWRA $\left(\mathrm{L} / \mathrm{m}^{3}\right)$ \\
\hline SCC & 450 & 0.4 & 834.0 & 926.6 & 180 & 4.45 \\
\hline
\end{tabular}

TABLE 2: Description of different curing techniques and the results of 28-day compressive strength and chloride permeability.

\begin{tabular}{|c|c|c|c|c|}
\hline Curing technique & Description & 28-day $f_{c}^{\prime}(\mathrm{MPa})$ & RCPT (coulombs) & $D_{a} \times 10^{-12}\left(\mathrm{~m}^{2} / \mathrm{sec}\right)$ \\
\hline 1 & 28 days in air at $23^{\circ} \mathrm{C}$ & 53.16 & 3000 & 9.33 \\
\hline 2 & 28 days in water at $23^{\circ} \mathrm{C}$ & 76.16 & 2072 & 7.52 \\
\hline 3 & 3 days in water and then air both at $23^{\circ} \mathrm{C}$ & 73.33 & 2130 & 8.86 \\
\hline 4 & 7 days in water and then air both at $23^{\circ} \mathrm{C}$ & 75.44 & 2100 & 8.32 \\
\hline 5 & 3 days in water at $23^{\circ} \mathrm{C}$ and then air at $3-5^{\circ} \mathrm{C}$ & 65.85 & 2596 & 7.99 \\
\hline 6 & 7 days in water at $23^{\circ} \mathrm{C}$ and then air at $3-5^{\circ} \mathrm{C}$ & 69.21 & 2432 & 7.85 \\
\hline 7 & 28 days in air at $3-5^{\circ} \mathrm{C}$ & 47.45 & 3120 & 9.62 \\
\hline 8 & 1 day in water at $50^{\circ} \mathrm{C}$ and then water at $23^{\circ} \mathrm{C}$ & 58.91 & 3093 & 12.2 \\
\hline 9 & 3 days in water at $50^{\circ} \mathrm{C}$ and then water at $23^{\circ} \mathrm{C}$ & 59.38 & 3633 & 15.0 \\
\hline 10 & 7 days in water at $50^{\circ} \mathrm{C}$ and then water at $23^{\circ} \mathrm{C}$ & 57.88 & 3700 & 18.0 \\
\hline
\end{tabular}

corrosion process was monitored by recording the current passed time and by taking half-cell measurements on a daily basis.

3.1. Materials and Mixture Design. In this study, type GU Canadian Portland cement, similar to ASTM Type I, with a specific gravity of 3.15, was used for the mixture. Natural sand and $10 \mathrm{~mm}$ maximum size stone were included as fine and coarse aggregates, respectively. The coarse and fine aggregates each had a specific gravity of 2.70 and water absorption of $1 \%$. A high range water reducer admixture (HRWRA), similar to ASTM Type F [20], was applied to attain the required slump flow diameter of the mixture. Reinforcing steel bars with the same diameter $(20 \mathrm{~mm})$ were used for the 80 prism samples. Table 1 presents the mixture proportions and the amount of HRWRA added to achieve a slump flow of $650 \mathrm{~mm}$, as per ASTM C1611 standard [21].

3.2. Casting, Curing, and Testing of Samples. After mixing the concrete and obtaining the required slump flow, 50 $(100 \mathrm{~mm} \times 200 \mathrm{~mm})$ cylinders and 80 prism samples with a $20 \mathrm{M}$ (200 mm diameter) steel bar at the centre of each prism were prepared. The 80 samples were divided into four groups representing four variable concrete covers: $20 \mathrm{~mm}$ (20 prisms), $30 \mathrm{~mm}$ (20 prisms), $40 \mathrm{~mm}$ (20 prisms), and $60 \mathrm{~mm}$ (20 prisms). The samples maintained equal clear concrete covers from all sides $(20,30,40$, and $60 \mathrm{~mm})$ by means of concrete spacers while each had the same length $(250 \mathrm{~mm})$. The dimensions of the samples were $60 \mathrm{~mm} \times 60 \mathrm{~mm} \times$ $250 \mathrm{~mm}$ for the $20 \mathrm{~mm}$ covers; $80 \mathrm{~mm} \times 80 \mathrm{~mm} \times 250 \mathrm{~mm}$ for the $30 \mathrm{~mm}$ covers; $100 \mathrm{~mm} \times 100 \mathrm{~mm} \times 250 \mathrm{~mm}$ for the $40 \mathrm{~mm}$ covers; and $140 \mathrm{~mm} \times 140 \mathrm{~mm} \times 250 \mathrm{~mm}$ for the $60 \mathrm{~mm}$ covers.

The samples (prisms and cylinders) were then cured under ten different curing techniques, as described in Table 2. The curing techniques were divided into four general categories, including air curing at $23^{\circ} \mathrm{C}$, water curing at $23^{\circ} \mathrm{C}$, heated-water curing at $50^{\circ} \mathrm{C}$, and cold-air curing at $3-5^{\circ} \mathrm{C}$.

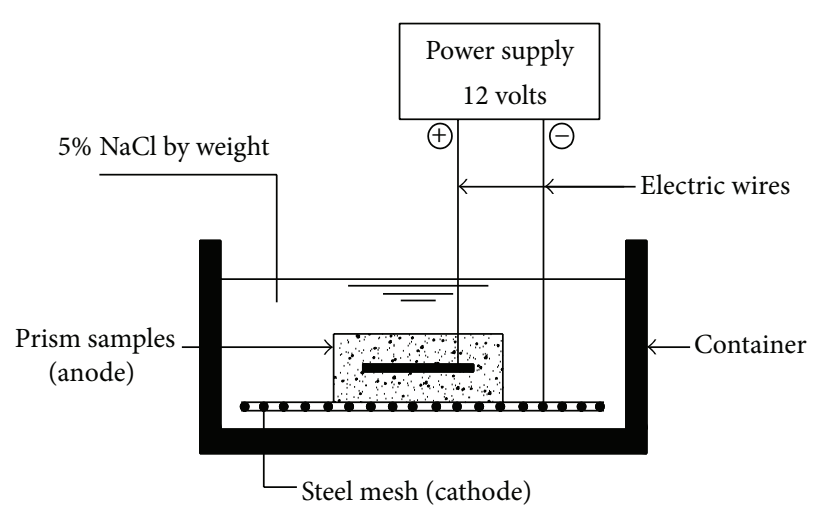

FIGURE 1: Accelerated corrosion test setup.

At 28 days, all the samples were removed from the different curing spots and left to dry before testing. The cylinders from each curing regime were tested to measure the compressive strength and chloride permeability for each curing system. Meanwhile, the 80 prisms were used in the accelerated corrosion test.

3.3. Accelerated Corrosion Test Setup. The accelerated corrosion setup was performed as shown in Figure 1. The samples were connected to a DC power supply acting as an anode $(+)$, while a steel mesh was positioned under the samples as a cathode (-). The samples were connected as parallel connections to the circuit board to maintain a constant voltage of 12 volts throughout the whole experiment. The 80 samples were totally submerged in a $5 \% \mathrm{NaCl}$ solution, as seen in Figure 1 [22]. The 80 prism samples were tested in two separate stages, including a nonsevere corrosion stage (40 prism samples) and a severe corrosion stage (40 prism samples). The samples tested in the nonsevere corrosion stage were denoted by 1 , while those samples in the severe corrosion stage were numbered as 2 . In the nonsevere corrosion stage, the samples were removed from the tank once the first 
crack was detected. On the other hand, the severe corrosion stage samples were left in the tank until sufficient damage ( $4 \mathrm{~mm}$ crack or more) was observed in the sample. The 40 samples in each stage were divided into four groups of ten prisms based on four concrete covers $(20,30,40$, and $60 \mathrm{~mm})$ and ten curing techniques (1 through 10). The samples were designated based on the stage of corrosion, cover thickness, and curing technique. For example, the sample tested in stage 1 (nonsevere corrosion stage) with a $40 \mathrm{~mm}$ concrete cover and cured in water for 28 days (curing technique 2) was designated as 1-40-2.

The corrosion activity was monitored daily for the 80 prism samples based on the values of the electrical current passed in each sample. The probability of corrosion was alternatively monitored using the half-cell potential test [23] by measuring the potential difference between the embedded steel bar and a reference electrode (copper-copper sulfate electrode). The readings were stopped upon reaching the first crack in the nonsevere corrosion stage and upon the appearance of a $4 \mathrm{~mm}$ thick crack in the severe corrosion stage.

\section{Corrosion Initiation Time Prediction Using Fick's Law of Diffusion}

Alternatively, the initiation period was calculated for ten selected samples ( $60 \mathrm{~mm}$ cover only) by means of Fick's second law of diffusion. After measuring the apparent chloride diffusion coefficients $\left(D_{a}\right)$ and the diffusion decay index $(m)$ for each sample, the following assumptions were made to predict the time to corrosion initiation of each sample under different curing systems.

(i) The structure has a clear concrete cover of $60 \mathrm{~mm}$.

(ii) The chloride threshold value is $0.05 \%$ (\% weight of concrete) as given from the literature $[3,12]$.

(iii) The chloride diffusion is the dominant mechanism and is governed by Fick's second law of diffusion in the following differential equation [24]:

$$
\frac{d C}{d t}=D_{a} *\left(\frac{d^{2} C}{d x^{2}}\right),
$$

where $C=$ the chloride content, $D_{a}=$ the apparent diffusion coefficient, $x=$ the depth from the exposed surface, and $t=$ time.

(iv) The chloride diffusion coefficients (at 28 days) decrease periodically as a function of time because of the cement hydration process. As a result, the chloride diffusion should be calculated at different time periods using [25]

$$
D(t)=D_{\text {ref }} *\left(\frac{t_{\text {ref }}}{t}\right)^{m}
$$

where $D(t)=$ diffusion coefficient at a time $t, D_{\text {ref }}=$ diffusion coefficient at time $t_{\text {ref }}$ (28 days), and $m=$ diffusion decay index. (v) The diffusion decay index $(m)$ of the ten selected samples was kept constant at $m=0.33$. This value was calculated using (2) by substituting the measured value of the diffusion coefficient at the age of 180 days of a concrete sample using curing technique 2 $\left(D_{180}=4.07 \times 10^{-12} \mathrm{~m}^{2} / \mathrm{sec}\right)$ with reference to $D_{28}=$ $7.52 \times 10^{-12} \mathrm{~m}^{2} / \mathrm{sec}$ (Table 2 ).

The surface chloride concentration $\left(C_{s}\right)$ of the simulated structure had reached a maximum value at the start time of chloride diffusion. This maximum surface chloride concentration was assumed as $C_{s}=0.8 \%$ weight of concrete to simulate structures located in marine splash zone [25]. In addition, this assumed value was very close to the average $C_{s}$ values obtained from the ten selected samples in the chloride bulk diffusion test as per ASTM C1556 [8]. The solution for estimating the time of corrosion initiation was implemented using a finite difference application of (1). The values of the chloride diffusion coefficient were varied at different time steps using (2) until the value of chloride concentration near the rebar surface reached the chloride threshold value $(0.05 \%$ weight of concrete). At this stage, the time was reported, indicating the corrosion initiation for each sample.

\section{Results and Discussions}

5.1. Effect of Different Curing Techniques on the Chloride Permeability. The results presented in Table 2 show that different curing techniques had a significant effect on the RCPT results. These results ranged between 2072 and 3700, which are classified as moderate penetrability, as per ASTM C1202. The curing technique with the minimum chloride permeability was technique number 2 , which involved curing the samples in water for 28 days at $23^{\circ} \mathrm{C}$. On the other hand, the maximum permeability was associated with technique number 10, which involved curing the samples in heated water at $50^{\circ} \mathrm{C}$ for a period of 7 days. Cold-curing samples (techniques 5, 6, and 7) had an average permeability of 2716, which was lower than the air-cured samples (technique 1).

Table 2 also showed that all water-curing techniques (2, 3 , and 4) had close RCPT permeability results. However, increasing the water-curing period at $23^{\circ} \mathrm{C}$ slightly decreased the chloride permeability (2130 to 2072 coulombs). With regard to the effect of cold-air curing, the chloride permeability in technique 7 (cured in cold air for 28 days) was higher than technique 1 (cured in normal air for 28 days). Moreover, when the samples in techniques 5 and 6 were subsequently cured in cold air after water-curing periods, the permeability was increased by approximately $15 \%$. It is obvious that heat-cured samples (techniques 8,9 , and 10) exhibited the maximum average chloride permeability. It is also clear that as the heat-curing period increases, the total charge passing increases, which represented higher permeability. The minimum RCPT between heat-cured samples was obtained from technique 8 , followed by technique 9 , and finally technique 10 . However, the difference between techniques 8,9 , and 10 was not significant.

Alternatively, the results from the chloride diffusion test also indicated a significant effect of the curing techniques on 


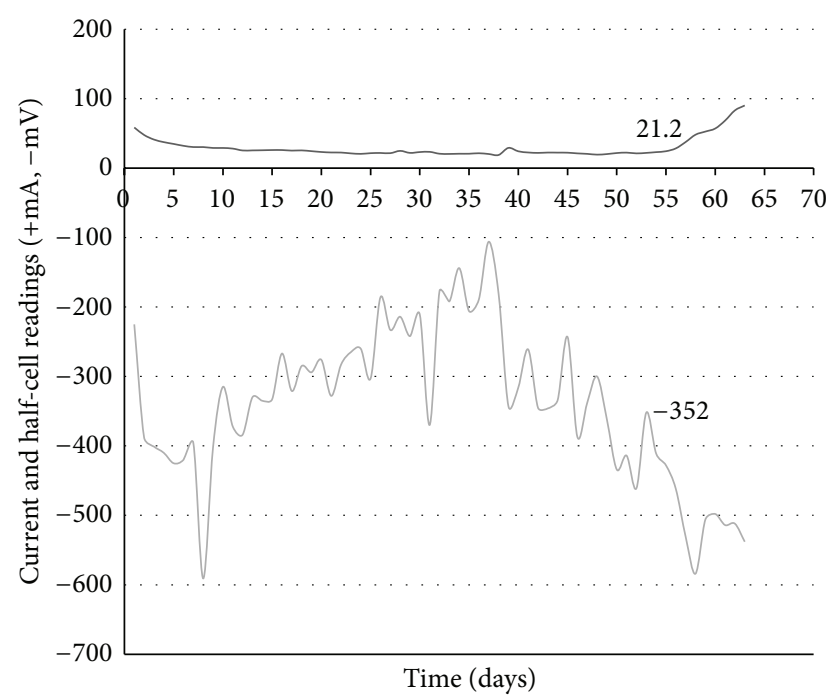

FIGURE 2: Time versus current and half-cell relationships for sample $1-60-2$.

the chloride permeability. It is clear from Table 2 that a minimum chloride diffusion coefficient of $7.52 \times 10^{-12} \mathrm{~m}^{2} / \mathrm{sec}$ was associated with the sample that had the minimum RCPT coulombs (technique 2). Moreover, a maximum value of $18.0 \times 10^{-12} \mathrm{~m}^{2} / \mathrm{sec}$ was obtained from technique 10 , which indicated the maximum chloride permeability. In fact, the effect of using different curing techniques on the chloride diffusion coefficients yielded an identical effect to that on the RCPT permeability.

5.2. Corrosion Initiation, Cracking, and Damage Times. Both of the electrical current readings and half-cell potential measurements were used to detect the corrosion initiation in the tested prism samples. Figure 2 demonstrates the general trend of the relationship for each of the current and half-cell readings versus time (sample number 1-60-2 as an example). The time of the corrosion initiation was detected at the point of the jump (sudden increase) in the current reading. It is clear from Figure 2 that the corrosion initiation occurred just after reaching a minimum value of the passing current of 21.2 $\mathrm{mA}$, which was followed by a sudden increase in the current (top part of Figure 2). This point was also confirmed from the half-cell potential reading ( -352 in Figure 2$)$ when a $90 \%$ probability of corrosion was achieved (potential values around $-350 \mathrm{mV}$, as per ASTM C876). It should be noted that that the critical value of half-cell potential reading $(-350 \mathrm{mV})$ cannot be solely used to detect corrosion initiation, as it can be overpassed during the first few days of testing, as seen from Figure 2. As a result, both the current and halfcell potential reading measurements were simultaneously checked to detect the corrosion initiation point.

By reviewing the electrical current and half-cell readings, the "corrosion initiation" was identified for each tested sample (Table 3). On the other hand, the cracking time was recorded for each tested sample once the first visual crack was observed. The results of the cracking times for all samples are

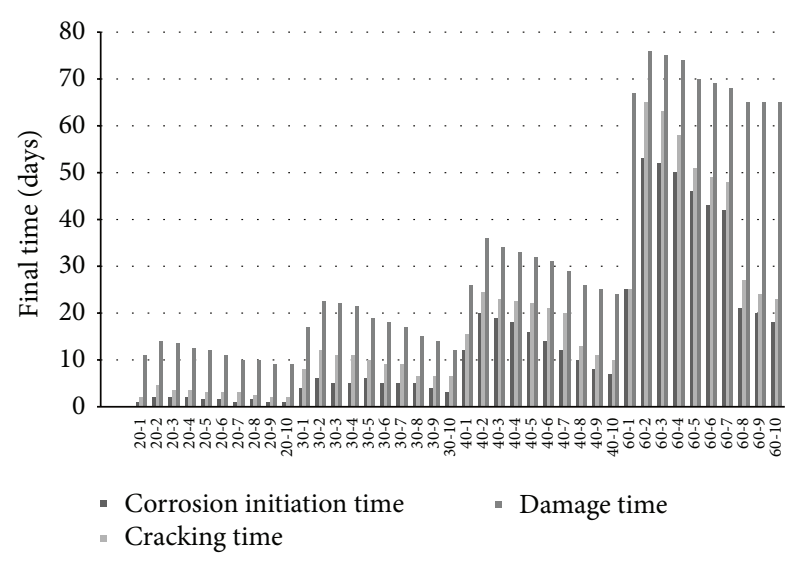

Figure 3: Corrosion initiation, cracking, and damage times.

shown in Table 3. In addition, the damage times for the tested samples were detected in the severe corrosion stage when a minimum crack width of $4 \mathrm{~mm}$ was observed (Table 3 ).

\subsection{Effect of the Concrete Cover Thickness on the Corrosion} Initiation, Cracking, and Damage Times. The results showed a minimum initiation period of 1 day associated with samples $1-20-1,1-20-7$, and 1-20-10, which had the minimum concrete cover along with high chloride permeability. On the other hand, the maximum period of 53 days was obtained from sample 1-60-2 with a $60 \mathrm{~mm}$ cover, as expected. This sample had a superior performance owing to the minimum chloride permeability along with the biggest concrete cover, which increased its resistance to corrosion. The concrete cover significantly affected the corrosion initiation times, as expected, because it provided resistance to corrosion [10]. For instance, the $20 \mathrm{~mm}$ cover had an average initiation period of 1.5 days, while the average initiation periods for 30,40 , and $60 \mathrm{~mm}$ covers were 5, 14, and 37 days, respectively (Table 3 and Figure 3).

It is also clear from Figure 3 that increasing the concrete cover from 20 to $60 \mathrm{~mm}$ increased the time of cracking. A minimum average time of about 3 days was obtained from the $20 \mathrm{~mm}$ samples; followed by the $30 \mathrm{~mm}$ samples, which took 9 days to crack; and then the $40 \mathrm{~mm}$ samples, which took an average of 18 days to crack. The maximum average time was 43 days and was obtained from the $60 \mathrm{~mm}$ cover samples, as expected. These results match the results of other studies that demonstrated the effect of the concrete cover on the time of concrete cracking [10].

Figure 3 also shows that $60 \mathrm{~mm}$ cover samples exhibited longer times to reach a crack of $4 \mathrm{~mm}$ (damage times) compared to 40,30 , and $20 \mathrm{~mm}$ cover samples. The differences between the time of cracking and the time of damage were showed to be approximately constant in the 20, 30, and $40 \mathrm{~mm}$ cover samples. The average differences were 8,9 , and 11 days for the 20,30 , and $40 \mathrm{~mm}$ cover samples, respectively (Table 3). However, the $60 \mathrm{~mm}$ samples had relatively higher differences between the time of cracking and the time of damage, as the average difference of these ten samples was 26 days. These results were attributed to the fact that at the 
TABLE 3: Experimental corrosion initiation, cracking, and damage periods for all samples.

\begin{tabular}{|c|c|c|c|c|c|}
\hline Prism sample & $\begin{array}{c}\text { Corrosion } \\
\text { initiation time } \\
\text { (days) }\end{array}$ & $\begin{array}{l}\text { Cracking time } \\
\text { (days) }\end{array}$ & Prism sample & $\begin{array}{l}\text { Damage time } \\
\text { (days) }\end{array}$ & $\begin{array}{c}\text { Predicted corrosion } \\
\text { initiation time (years) }\end{array}$ \\
\hline $1-20-1$ & 1 & 2 & $2-20-1$ & 11 & - \\
\hline $1-20-2$ & 2 & 4.5 & $2-20-2$ & 14 & - \\
\hline $1-20-3$ & 2 & 3.5 & $2-20-3$ & 13.5 & - \\
\hline $1-20-4$ & 2 & 3.5 & $2-20-4$ & 12.5 & - \\
\hline $1-20-5$ & 1.5 & 3 & $2-20-5$ & 12 & - \\
\hline $1-20-6$ & 1.5 & 3 & $2-20-6$ & 11 & - \\
\hline $1-20-7$ & 1 & 3 & $2-20-7$ & 10 & - \\
\hline $1-20-8$ & 1.5 & 2.5 & $2-20-8$ & 10 & - \\
\hline $1-20-9$ & 1 & 2 & $2-20-9$ & 9 & - \\
\hline $1-20-10$ & 1 & 2 & $2-20-10$ & 9 & - \\
\hline $1-30-1$ & 4 & 8 & $2-30-1$ & 17 & - \\
\hline $1-30-2$ & 6 & 12 & $2-30-2$ & 22.5 & - \\
\hline $1-30-3$ & 5 & 11 & $2-30-3$ & 22 & - \\
\hline $1-30-4$ & 5 & 11 & $2-30-4$ & 21.5 & - \\
\hline $1-30-5$ & 6 & 10 & $2-30-5$ & 19 & - \\
\hline $1-30-6$ & 5 & 9 & $2-30-6$ & 18 & - \\
\hline $1-30-7$ & 5 & 9 & $2-30-7$ & 17 & - \\
\hline $1-30-8$ & 5 & 6.5 & $2-30-8$ & 15 & - \\
\hline $1-30-9$ & 4 & 6.5 & $2-30-9$ & 14 & - \\
\hline $1-30-10$ & 3 & 6.5 & $2-30-10$ & 12 & - \\
\hline $1-40-1$ & 12 & 15.5 & $2-40-1$ & 26 & - \\
\hline $1-40-2$ & 20 & 24.5 & $2-40-2$ & 36 & - \\
\hline $1-40-3$ & 19 & 23 & $2-40-3$ & 34 & - \\
\hline $1-40-4$ & 18 & 22.5 & $2-40-4$ & 33 & - \\
\hline $1-40-5$ & 16 & 22 & $2-40-5$ & 32 & - \\
\hline $1-40-6$ & 14 & 21 & $2-40-6$ & 31 & - \\
\hline $1-40-7$ & 12 & 20 & $2-40-7$ & 29 & - \\
\hline $1-40-8$ & 10 & 13 & $2-40-8$ & 26 & - \\
\hline $1-40-9$ & 8 & 11 & $2-40-9$ & 25 & - \\
\hline $1-40-10$ & 7 & 10 & $2-40-10$ & 24 & - \\
\hline $1-60-1$ & 25 & 25 & $2-60-1$ & 67 & 2 \\
\hline $1-60-2$ & 53 & 65 & $2-60-2$ & 76 & 3.8 \\
\hline $1-60-3$ & 52 & 63 & $2-60-3$ & 75 & 3.2 \\
\hline $1-60-4$ & 50 & 58 & $2-60-4$ & 74 & 3.4 \\
\hline $1-60-5$ & 46 & 51 & $2-60-5$ & 70 & 3.5 \\
\hline $1-60-6$ & 43 & 49 & $2-60-6$ & 69 & 3.6 \\
\hline $1-60-7$ & 42 & 48 & $2-60-7$ & 68 & 2.6 \\
\hline $1-60-8$ & 21 & 27 & $2-60-8$ & 65 & 1.8 \\
\hline $1-60-9$ & 20 & 24 & $2-60-9$ & 65 & 1.3 \\
\hline $1-60-10$ & 18 & 23 & $2-60-10$ & 65 & 1 \\
\hline
\end{tabular}

stage of damage the effect of concrete resistivity (in terms of chloride permeability or chloride diffusion) was not a factor since the cracks were already open for chlorides to reach the reinforcing bars. However, the relatively higher difference that occurred in the $60 \mathrm{~mm}$ samples may be attributed to the longer time the $4 \mathrm{~mm}$ crack took to show on a higher cover thickness.
5.4. Effect of Different Curing Techniques on the Corrosion Initiation, Cracking, and Damage Times. Figure 3 shows that different initiation times were warranted for each curing technique associated with a certain concrete cover. It is obvious from the figure that minimum initiation periods were obtained from curing technique 10 (heat curing at $50^{\circ} \mathrm{C}$ ). The maximum initiation periods were seen in samples cured 
using technique 2 (water curing at $23^{\circ} \mathrm{C}$ ). It is also clear that normal water-cured samples (techniques 2,3 , and 4) had the maximum times to corrosion, higher than both cold air-cured $(5,6$, and 7$)$ and heated water-cured $(8,9$, and 10$)$ techniques. In addition, the normal-temperature air-cured sample at $23^{\circ} \mathrm{C}$ (technique 1) had longer initiation periods than all heated water-cured samples. However, the differences among the normal water-cured, cold air-cured, and heated water-cured samples were not significant. For example, in $60 \mathrm{~mm}$ cover samples these differences ranged from 50 to 53 days, 42 to 46 days, and 18 to 21 days for normal water-cured, cold air-cured, and heated water-cured samples, respectively (Table 3 ). The results also showed that increasing the water-curing period from 3 to 28 days (at $23^{\circ} \mathrm{C}$ ) increased the corrosion initiation times by approximately $6 \%$. On the contrary, increasing the cold air-curing times (at $3-5^{\circ} \mathrm{C}$ ) from 21 to 28 days yielded a $9 \%$ reduction in the corrosion initiation times. Moreover, extending the heat-curing periods (at $50^{\circ} \mathrm{C}$ ) from 1 to 7 days was found to minimize the corrosion initiation times by almost $15 \%$.

On the other hand, different curing techniques showed different cracking times between the ten samples with the same concrete cover $(20,30,40$, and $60 \mathrm{~mm})$. The first cracked samples were those cured in air and heat, followed by cold-cured samples, and finally the water-cured samples. For example, in the $60 \mathrm{~mm}$ cover samples, heatcured samples cracked at an average of 24 days, followed by air-cured samples (at $23^{\circ} \mathrm{C}$ ), and then cold-air samples (at $3-5^{\circ} \mathrm{C}$ ), which cracked at an average of 25 and 49 days, respectively. The last samples were the water-cured samples at $23^{\circ} \mathrm{C}$; those samples showed an average cracking time of 62 days. These results were attributed to the low concrete resistivity of the samples cured in heat (technique 10) and the high concrete resistivity of the samples cured in normaltemperature water (technique 2). This resistivity was also observed from the results of the RCPT and chloride diffusion tests.

It can also be seen in Figure 3 that different cracking times were obtained in each curing technique based on the curing period applied in the technique. For example, in $60 \mathrm{~mm}$ cover samples, increasing the water-curing period from 3 to 28 days resulted in an extension of the cracking times by approximately $10 \%$ (Table 3 ). Extending the cold air-curing period (at $3-5^{\circ} \mathrm{C}$ ) from 21 to 28 days in the same cover samples was found to decrease the cracking times by nearly $6 \%$. Moreover, longer heat-curing periods (at $50^{\circ} \mathrm{C}$ ) in $60 \mathrm{~mm}$ samples yielded a reduction in the time to cracking by about $15 \%$. It should be noted that the trends obtained from $60 \mathrm{~mm}$ cover samples were almost identical in other concrete covers $(20,30$, and $40 \mathrm{~mm})$.

The effect of the curing period on the damage times was found to be relatively insignificant compared to the same effect on the cracking times. For instance, when the watercuring period (at $23^{\circ} \mathrm{C}$ ) was increased from 3 to 28 days in $60 \mathrm{~mm}$ cover, as an example, the time to damage increased by nearly $3 \%$ only (Table 3 ). On the other hand, increasing the cold-air curing (at $3-5^{\circ} \mathrm{C}$ ) from 21 to 28 days, or the heat curing $\left(\right.$ at $50^{\circ} \mathrm{C}$ ) from 1 to 7 days, resulted in a reduction in the damage periods by almost $3 \%$. These results may also

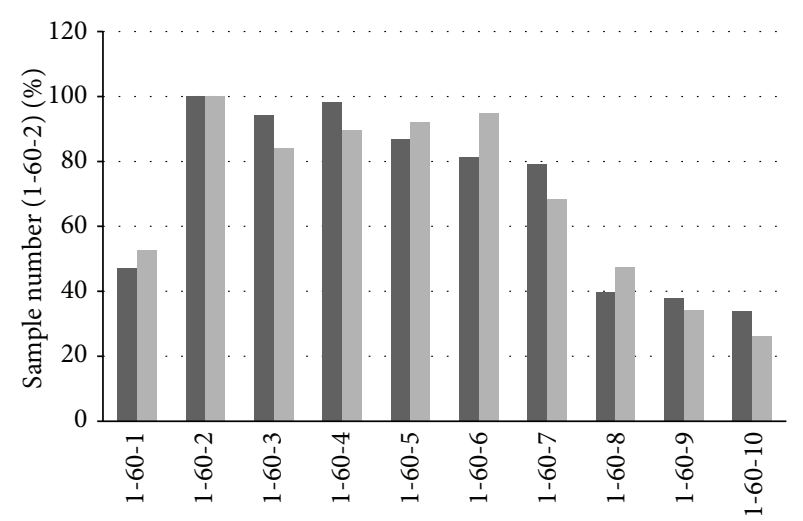

FIGURE 4: Initiation periods from Fick's law and accelerated corrosion test for the $60 \mathrm{~mm}$ cover samples.

be attributed to the increasing width of cracks at this stage, which minimized the contribution of the concrete resistivity.

5.5. Comparison of the Corrosion Initiation Times from Fick's Law and Accelerated Corrosion Experiment. Table 3 presents the results of the corrosion initiation periods obtained from the accelerated corrosion test and the expected periods obtained from Fick's law of diffusion. Only $60 \mathrm{~mm}$ cover samples were included in this evaluation. To simplify the comparison, the results of the accelerated corrosion test and the predicted values from Fick's law were normalized as a percentage of the maximum period obtained from sample 1-60-2. The results from the accelerated corrosion test are described as a percentage of days with respect to sample 1-602 , while the results from Fick's law are shown as a percentage of years with respect to sample 1-60-2 (Figure 4). It is obvious from Figure 4 that the differences between both methods (accelerated corrosion versus Fick's law) were almost nonsignificant. It should be noted that the accelerated corrosion test in this investigation cannot be used to predict the actual corrosion time of reinforced concrete structures. However, it was used in this investigation as a comparative study only to check the effectiveness of Fick's second law based prediction model and to illustrate the different corrosion stages during the overall service life of the concrete structure.

\section{Conclusions}

The following conclusions were drawn from this investigation.

(i) Water curing for a period of 28 days (at $23^{\circ} \mathrm{C}$ ) proved to be the best curing system (compared to air, cold, and heat curing) in terms of compressive strength, chloride permeability, and corrosion resistance. The 28-day water-cured samples (curing technique 2) had the longest times to show signs of corrosion initiation, cracking, and damage among all tested samples, under the curing conditions of the present tests. 
(ii) Among all tested samples, the first samples that showed corrosion initiation, cracking, and damage were those cured in heated water for 7 days at $50^{\circ} \mathrm{C}$.

(iii) Increasing the water-curing period from 3 to 28 days (at $23^{\circ} \mathrm{C}$ ) in techniques 2,3 , and 4 , regardless of the concrete cover thickness, decreased the chloride permeability, increased the 28-day compressive strength, and increased the corrosion initiation, cracking, and damage times by approximately $6 \%, 10 \%$, and $3 \%$, respectively.

(iv) The increase in the cold air-curing times (at $3-5^{\circ} \mathrm{C}$ ) from 21 to 28 days in techniques 5,6 , and 7 for all tested concrete covers maximized the chloride permeability, reduced the 28-day compressive strength, and yielded a reduction of the corrosion initiation, cracking, and damage times by about $9 \%, 6 \%$, and $3 \%$, respectively.

(v) Extending the heat-curing periods $\left(\right.$ at $50^{\circ} \mathrm{C}$ ) from 1 to 7 days in techniques 8,9 , and 10 for all concrete cover samples was found to reduce the corrosion initiation, cracking, and damage times by almost $14 \%, 15 \%$, and $3 \%$, respectively.

(vi) The trend of the results of the corrosion initiation periods obtained from the accelerated corrosion test was similar to that obtained from Fick's second law of diffusion for counterpart samples, under the same assumptions of the present study.

(vii) The results of the electrical current readings concur with those of the half-cell potential measurements in all tested samples. The corrosion initiation was found to occur at the first jump of the current measurement and at half-cell potential reading values around $-350 \mathrm{mV}$, which indicate $90 \%$ probability of corrosion, as per ASTM C876.

\section{Conflict of Interests}

The authors do not have any conflict of interests with regard to the content of the paper.

\section{References}

[1] B. Martin-Peréz, S. J. Pantazopoulou, and M. D. A. Thomas, "Finite element modelling of corrosion in r.c. highway structures," in Proceedings of the Concrete under Severe Conditions 2: Environment and Loading, pp. 354-363, E \& FN Spon, London, UK, 1998.

[2] A. Boddy, E. Bentz, M. D. A. Thomas, and R. D. Hooton, "An overview and sensitivity study of a multimechanistic chloride transport model," Cement and Concrete Research, vol. 29, no. 6, pp. 827-837, 1999.

[3] M. A. Ehlen, M. D. A. Thomas, and E. C. Bentz, "Life-365 service life prediction Model Version 2.0," Concrete International, vol. 31, no. 5, pp. 41-46, 2009.

[4] E. Güneyisi, M. Gesoglu, and E. Özbay, "Permeation properties of self-consolidating concretes with mineral admixtures," $A C I$ Materials Journal, vol. 108, no. 2, pp. 150-158, 2011.
[5] R. D. Hooton, M. R. Geiker, and E. C. Bentz, "Effects of curing on chloride ingress and implications on service life," ACI Materials Journal, vol. 99, no. 2, pp. 201-206, 2002.

[6] S. Sujjavanich, V. Sida, and P. Suwanvitaya, "Chloride permeability and corrosion risk of high-volume fly ash concrete with mid-range water reducer," ACI Materials Journal, vol. 102, no. 3, pp. 177-182, 2005.

[7] ASTM International, "Standard test method for electrical indication of concrete's ability to resist chloride ion penetration," in Annual Book of ASTM Standards, ASTM C1202-97, ASTM International, West Conshohocken, Pa, USA, 1997.

[8] ASTM C1556-11a, "Standard test method for determining the apparent chloride diffusion coefficient of cementitious mixtures by bulk diffusion," in Annual Book of ASTM Standards, ASTM International, West Conshohocken, Pa, USA, 2011.

[9] P. Pun, Influence of silica fume on chloride resistance of concrete [M.S. thesis], Department of Civil Engineering, University of Toronto, Toronto, Canada, 1997.

[10] K. A. T. Vu and M. G. Stewart, "Structural reliability of concrete bridges including improved chloride-induced corrosion models," Structural Safety, vol. 22, no. 4, pp. 313-333, 2000.

[11] T. El Maaddawy and K. Soudki, "A model for prediction of time from corrosion initiation to corrosion cracking," Cement and Concrete Composites, vol. 29, no. 3, pp. 168-175, 2007.

[12] D. Trejo and R. G. Pillai, "Accelerated chloride threshold testing: part I-ASTM A 615 and A 706 reinforcement," ACI Materials Journal, vol. 100, no. 6, pp. 519-527, 2003.

[13] L. Amleh and S. Mirza, "Corrosion influence on bond between steel and concrete," ACI Structural Journal, vol. 96, no. 3, pp. 415-423, 1999.

[14] R. J. Detwiler, K. O. Kjellsen, and O. E. Gjorv, "Resistance to chloride intrusion of concrete cured at different temperatures," ACI Materials Journal, vol. 88, no. 1, pp. 19-24, 1991.

[15] Y. Auyeung, P. Balaguru, and L. Chung, "Bond behavior of corroded reinforcement bars," ACI Structural Journal, vol. 97, no. 2, pp. 214-221, 2000.

[16] J. A. Mullard and M. G. Stewart, "Corrosion-induced cover cracking: new test data and predictive models," ACI Structural Journal, vol. 108, no. 1, pp. 71-79, 2011.

[17] P. S. Mangat and M. S. Elgarf, "Flexural strength of concrete beams with corroding reinforcement," ACI Structural Journal, vol. 96, no. 1, pp. 149-158, 1999.

[18] A. A. Hassan, K. M. A. Hossain, and M. Lachemi, "Structural assessment of corroded self-consolidating concrete beams," Engineering Structures, vol. 32, no. 3, pp. 874-885, 2010.

[19] S. Ahmad, B. Bhattacharjee, and R. Wason, "Experimental service life prediction of rebar-corroded reinforced concrete structure," ACI Materials Journal, vol. 94, no. 4, pp. 311-316, 1997.

[20] ASTM C494/C494M-13, "Standard specification for chemical admixtures for concrete," in Annual Book of ASTM Standards, ASTM International, West Conshohocken, Pa, USA, 2013.

[21] ASTM C1611-09be1, "Standard test method for slump flow of self-consolidating concrete," in Annual Book of ASTM Standards, ASTM International, West Conshohocken, Pa, USA, 2009.

[22] A. A. A. Hassan, K. M. A. Hossain, and M. Lachemi, "Corrosion resistance of self-consolidating concrete in full-scale reinforced beams," Cement and Concrete Composites, vol. 31, no. 1, pp. 2938, 2009. 
[23] ASTM C876-91, "Standard test method for half-cell potentials of uncoated reinforcing steel in concrete," Annual Book of ASTM Standards, ASTM International, West Conshohocken, Pa, USA, 1991.

[24] O. E. Gjørv, "Durability and service life of concrete structures," in Proceedings of the 1st fib Congress, pp. 1-16, Japan Prestressed Concrete Engineering Association, Tokyo, Japan, 2002.

[25] E. C. Bentz and M. D. A. Thomas, "Life-365 service life prediction model and computer program for predicting the service life and life-cycle cost of reinforced concrete exposed to chlorides," in User Manual, Version 2.1, pp. 1-87, 2012. 

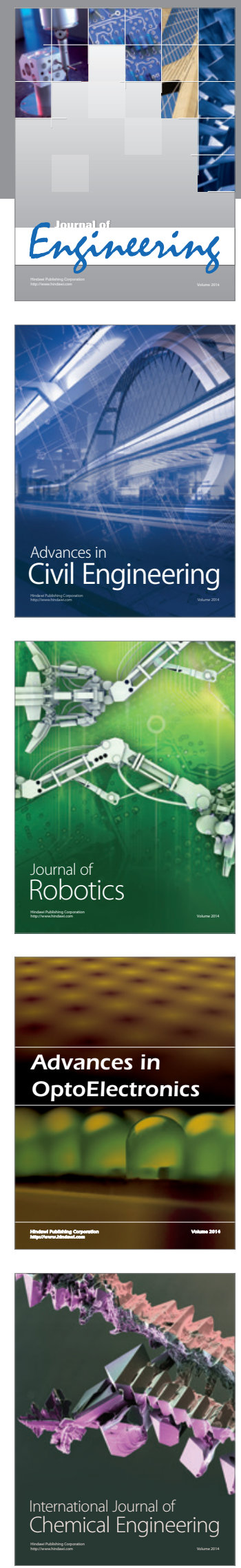

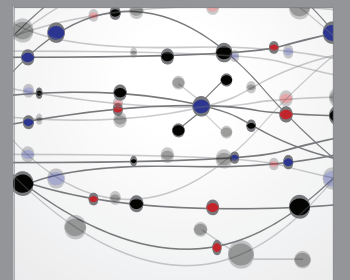

The Scientific World Journal
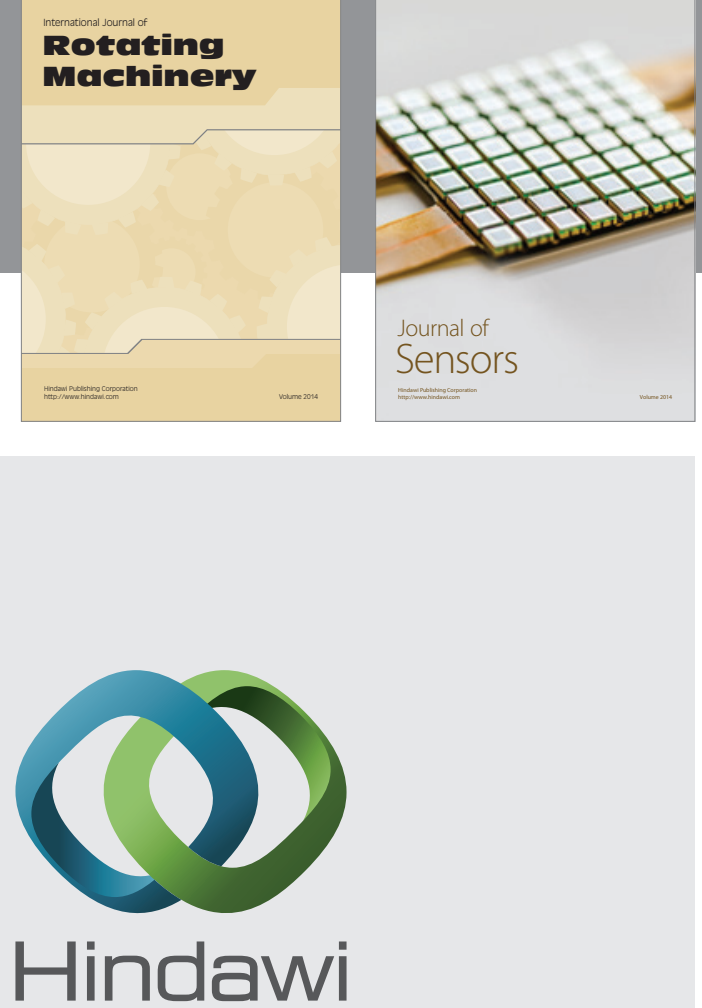

Submit your manuscripts at http://www.hindawi.com
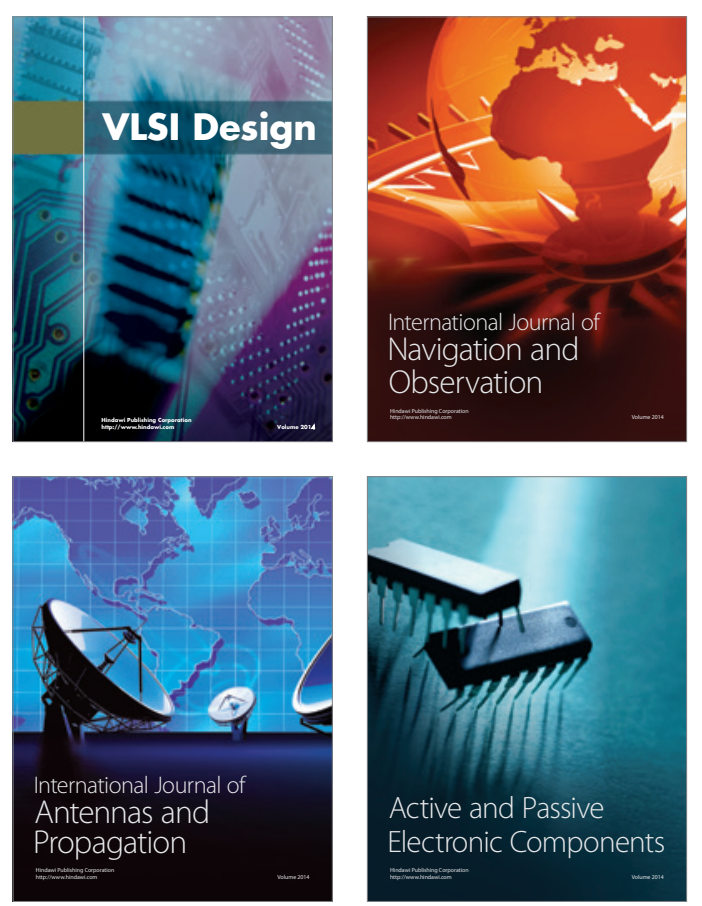
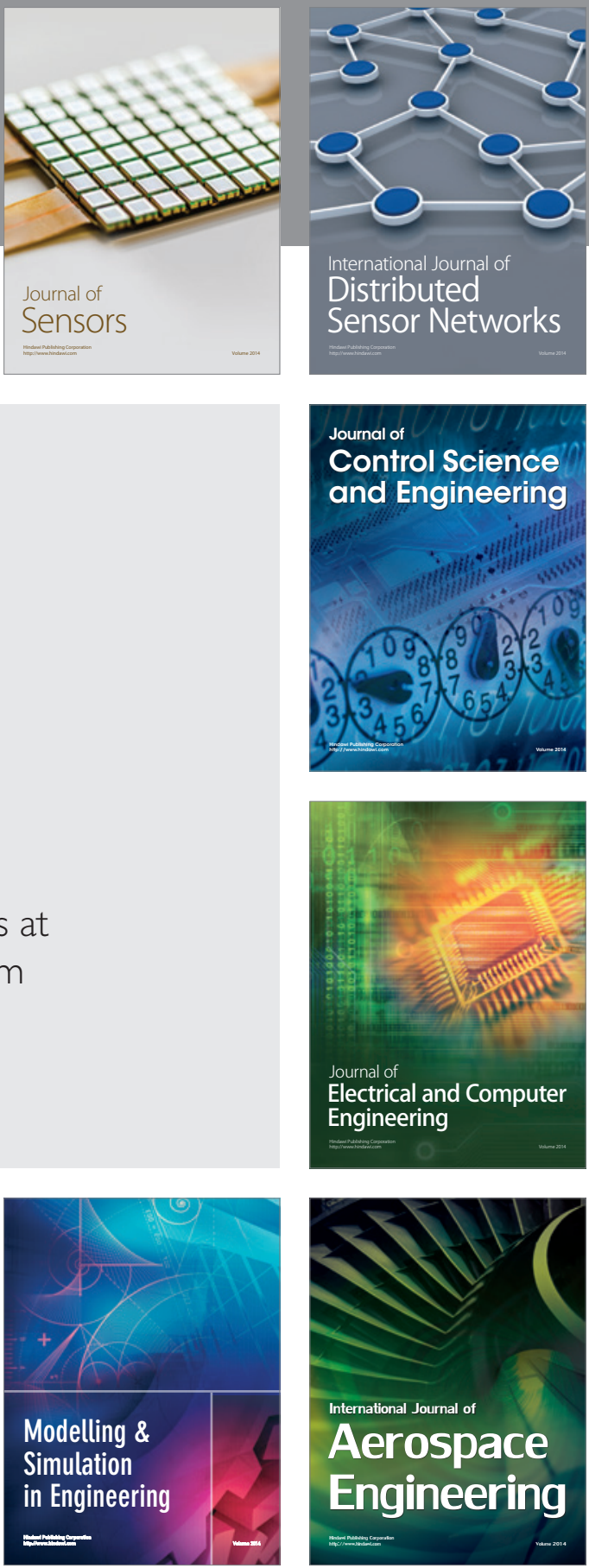

Journal of

Control Science

and Engineering
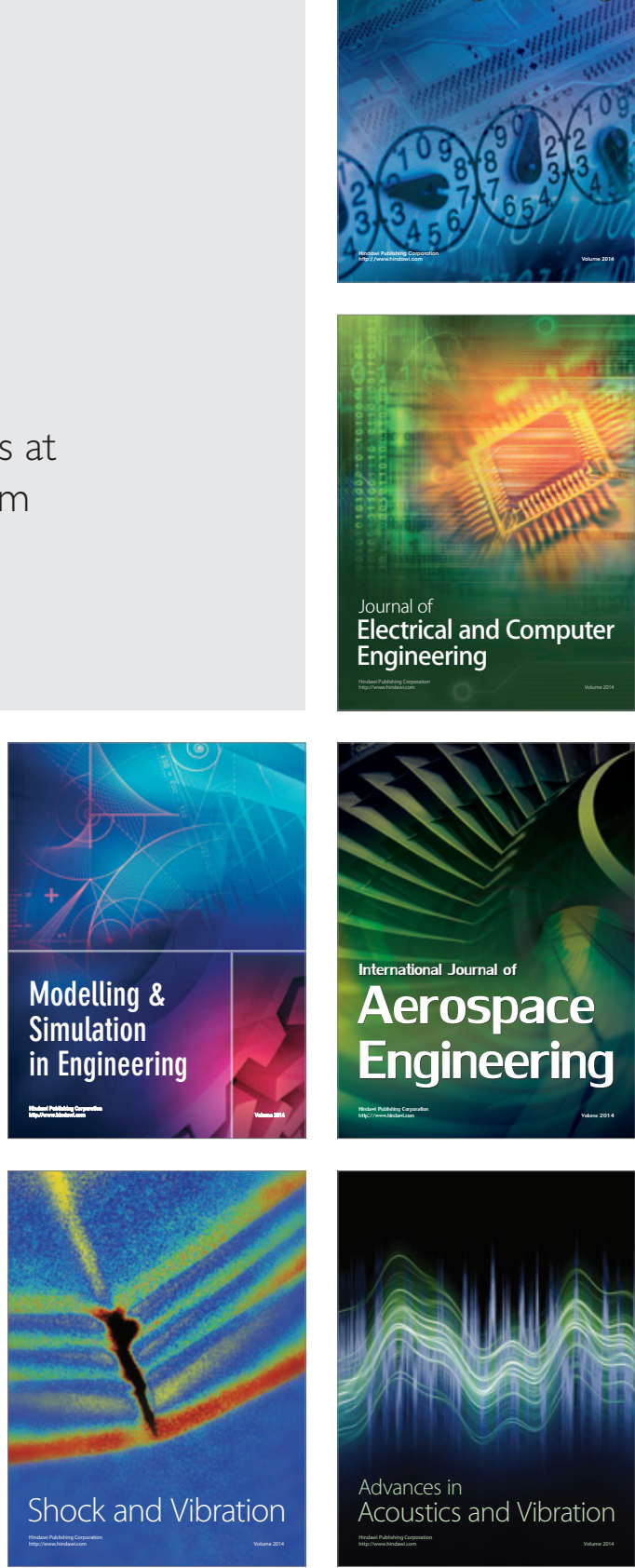